\title{
Large-Scale Distribution of Peroxyacetylnitrate Results From the STRATOZ III Flights
}

\author{
J. RUDOLPH, B. VIERKORN-RUdOLPH, AND F. X. MEIXNER ${ }^{1}$
}

Atmosphärische Chemie, Institut für Chemie 3, Kernforschungsanlage Jülich G.m.b.H., Jülich, Federal Republic of Germany

\begin{abstract}
During the STRATOZ III flights in June 1984, approximately 160 measurements of peroxyacetylnitrate (PAN) were made with a specially designed gas chromatograph on board the Caravelle 116 airplane. The measurements cover a latitude range from $70^{\circ} \mathrm{N}$ to $60^{\circ} \mathrm{S}$ and altitudes up to $12 \mathrm{~km}$. The results show that PAN is present throughout the troposphere at low but measurable levels. Southern hemispheric data from clean marine air masses show levels of 7-10 ppt, with little variability up to about $10 \mathrm{~km}$ altitude. In the southern uppermost troposphere and lowest stratosphere a significant increase in PAN can be seen, indicating substantial in situ formation of PAN at these altitudes. The situation at lower latitudes in the northern hemisphere is similar as long as the air masses are free of anthropogenic influence. At mid and high northern latitudes, considerably higher PAN mixing ratios (sometimes more than $100 \mathrm{ppt}$ ) are found even outside continental areas. These data also show a rather high variability. This can be ascribed to the influence of North America and Europe as source areas for PAN and PAN precursors.
\end{abstract}

\section{INTRODUCTION}

During the past few years it has been recognized that peroxyacetylnitrate (PAN) is not only an important component of urban photochemical smog, but may also be of considerable importance for the chemistry of the nonurban and remote troposphere [Brewer et al., 1983; Fishman and Carney, 1984]. Crutzen [1979] and Singh and Hanst [1981] hypothesized that PAN may act as an important reservoir for reactive nitrogen and serve as a "transport medium" for $\mathrm{NO}_{x}$. PAN is formed during the photochemical oxidation of nonmethane hydrocarbons in the presence of $\mathrm{NO}_{2}$, and thus the knowledge of the tropospheric PAN distribution may help to better understand the photochemistry of the troposphere and can serve as an important tool to validate photochemical models.

In contrast to the large number of PAN measurements in urban, polluted areas (see, for example, Temple and Taylor [1983]) there are few series of measurements over rural and semirural areas [Spicer et al., 1983; Meyrahn et al., 1984; Brice et al., 1984; Penkett et al., 1975], and extremely limited data are available for the remote troposphere or from above ground level [Singh and Salas, 1983, Singh et al., 1986]. There are also some studies of PAN and $\mathrm{NO}_{x}$ together with several other atmospheric trace gases [Bottenheim et al., 1986; Fahey et al., 1986; Singh et al., 1985]. However, these studies were made at ground-level continental sites. No simultaneous measurements of PAN and $\mathrm{NO}_{x}$ in the free troposphere have yet been published.

In 1984 a flight mission called "STRATOZ III" was performed in cooperation between several French and German research groups. The flights covered a latitude range from about $70^{\circ} \mathrm{N}$ to $60^{\circ} \mathrm{S}$ and altitudes between ground level and 12 $\mathrm{km}$. Several important atmospheric trace components were investigated during these flights. In this paper the results of

\footnotetext{
${ }^{1}$ Now at Fraunhofer-Institut für Atmosphärische Umweltforschung, Garmisch-Partenkirchen, Federal Republic of Germany.

Copyright 1987 by the American Geophysical Union.

PAN measurements obtained with a gas chromatograph on board the Caravelle 116 airplane are presented.

\section{EXPERIMENTAL TECHNIQUE}

The STRATOZ III mission was conducted in cooperation with the French Etablissement d'Etudes et de Recherche Météorologiques (EERM) at Toulouse and the Centre d'Essais en Vol (CEV) at Bretigny sur l'Orge. The flight of the Caravelle 116 started on June 4, 1984, at Bretigny and went via Scotland, Iceland, and southern Greenland along the North American east coast and the South American west coast to Punta Areas in southern Chile and then back along the east coast of South America and the west coast of Africa and Europe to Bretigny. The flights ended on June 26. The flight route is shown in Figure 1, together with the locations of PAN measurements. PAN was measured in situ with a specially designed gas chromatograph on board the airplane.

PAN is separated on a PEG 400 column $(5 \%$ on Chromosorb W HP, 80/100 mesh) with a total length of $1.3 \mathrm{~m}$ (1-m separation column and $0.3-\mathrm{m}$ precolumn) and $2 \mathrm{~mm}$ ID. The column temperature is kept at $290 \mathrm{~K}$, slightly below ambient temperature, with an oven equipped with Peltier elements. The sample is preconcentrated at $195 \mathrm{~K}$ in a glass loop of $1-\mathrm{m}$ length and $4 \mathrm{~mm}$ ID. Sample flow rate through the enrichment column is $100 \mathrm{~cm}^{3} \mathrm{~min}^{-1}$ (STP). Duration of the preconcentration is $20 \mathrm{~min}$. For injection the sample loop is allowed to warm up to $\approx 290 \mathrm{~K}$. During warming of the sample loop the sample loop is closed by means of a four-way valve in order to prevent broadening of the sample input profile. Sample enrichment and injection is controlled by a conventional 10-way valve, which also allows backflush of the 0.3-m precolumn. This avoids contamination of the electron capture detector by atmospheric trace components of low volatility. This is essential since the detector is kept at exactly $325 \mathrm{~K}$ for optimum sensitivity for PAN. The carrier gas is nitrogen, with a flow rate of $50 \mathrm{~cm}^{3} \mathrm{~min}^{-1}$ (STP).

The retention time of PAN is $11 \mathrm{~min}$. The absence of interference is checked with a potassium hydroxide scrubber. This scrubber consists of a glass or polytetrafluoro ethylene (PTFE) tube with $4 \mathrm{~mm}$ ID packed with $2-\mathrm{mm}$ glass beads, coated 


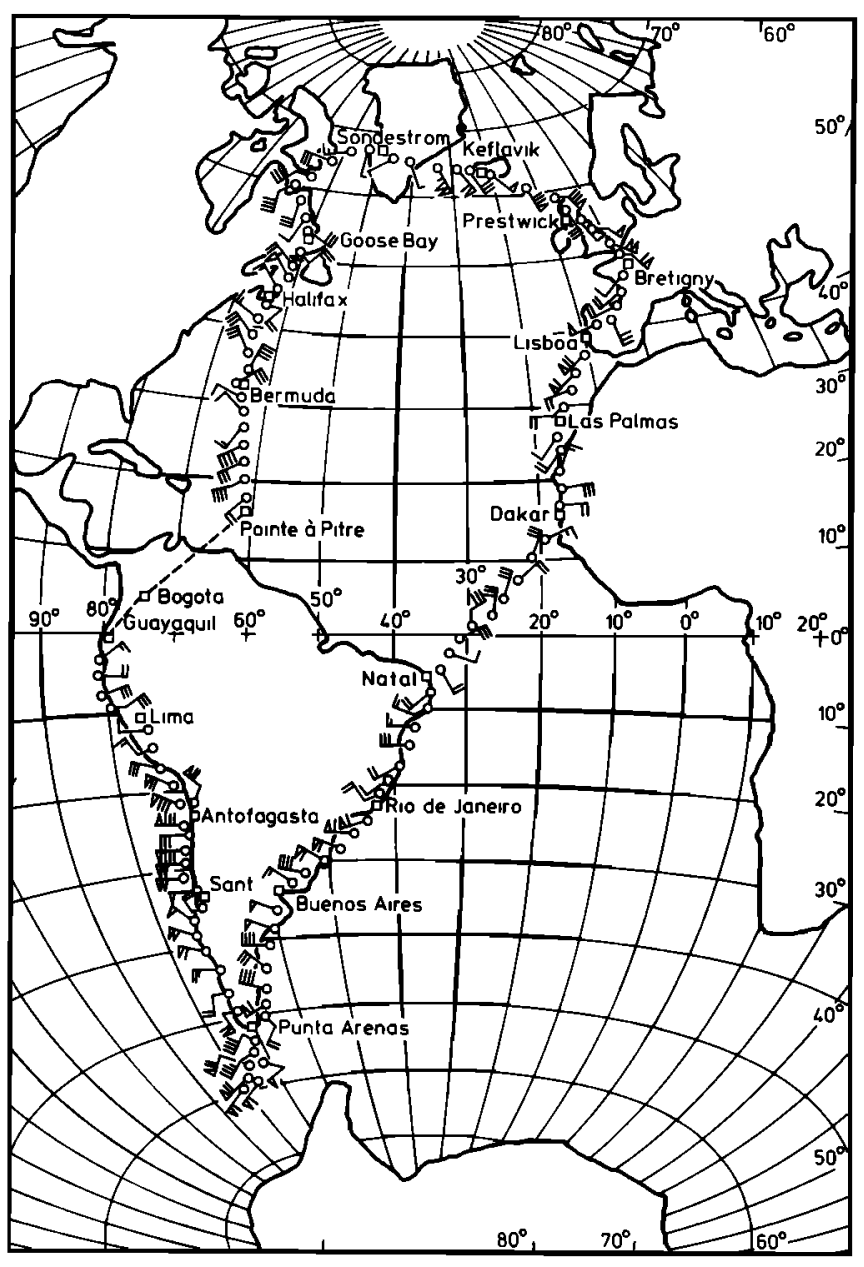

Fig. 1. Flight route of the STRATOZ III mission and location of PAN measurements. The wind vane indicates the average wind direction and velocity during the PAN measurements.

with potassium hydroxide. The length of the tube has to be adjusted to the sample flow rate through the tube to allow a residence time of a few tenths of a second. Such a scrubber removes PAN quantitatively from the sample gas stream. Under these conditions no detectable peak with a retention time corresponding to PAN could be observed either in ambient air and or in calibration mixtures containing ppb levels of PAN.

The instrument was directly calibrated with PAN mixtures prepared in a three-step dynamic dilution system down to 100 ppt. Lower amounts of PAN were injected by reducing the total sample volume up to a factor of about 10 , resulting in a lower limit of calibration of $20 \mathrm{dm}^{3} \mathrm{ppt}$, corresponding to 10 ppt in a $2 \mathrm{dm}^{3}$ sample.

Fast checks of the instrument performance were made by injecting small amounts of $n$-propylnitrate (dissolved in $n$ pentane or $n$-heptane), which has a slightly longer retention time compared to PAN and a very similar electron capture detector response but is considerably more stable than PAN and therefore easier to handle. The detection limit of the experimental procedure is $1 \mathrm{ppt}(3 \sigma)$, the precision of the measurements above 5 ppt is about $10 \%$, and the estimated accuracy is roughly $20 \%$. Because of limited linear range of the electron capture detector, this measurement technique is only linear up to about 500 ppt. However, this value was never exceeded during the STRATOZ III flights. A detailed description of the measurement technique is given by Vierkorn-Rudolph et al. [1985].

The instrument was connected to an air intake tube mounted on a flange on top of the airplane cabin. The intake lines were Teflon lined ( $4 \mathrm{~mm}$ ID, about $4 \mathrm{~m}$ in length) and continuously flushed with outside air at a rate of approximately $15 \mathrm{dm}^{3} \mathrm{~min}^{-1}$. Thus the residence time of the sampled air from the intake to the measuring instrument was less than 0.5 s. Laboratory tests verified that under these conditions no detectable change in the PAN mixing ratios of the sampled air occurred.

Because of a defect in the electronic power supply of the instrument at Point à Pitré which could, because of missing spare parts, not be immediately repaired, the instrument did not operate during the flights from Point à Pitré to Bogota and from Bogota to Guayaquil. Throughout the other 19 flights the instrument worked properly, and measurements were made at intervals of $30 \mathrm{~min}$.

\section{RESULTS}

Nearly 160 PAN measurements were made during 19 of the 21 STRATOZ III flights, including 40 measurements at the different airports. The flights covered a latitude range from $\approx 70^{\circ} \mathrm{N}$ to $60^{\circ} \mathrm{S}$ and altitudes up to $12 \mathrm{~km}$ (Figures 1 and 2 ). In Figure 1 the average windspeed and wind direction during the sampling periods are also shown in order to give some impression of the possible impact of local or regional pollution, continents, etc. Since the samples were collected over a period of $20 \mathrm{~min}$, the individual points represent the mean of a 150- to $200-\mathrm{km}$ horizontal distance. For technical reasons the ascent and descent rates of the airplane varied considerably. Consequently, the measurements were integrated over a varying altitude range. Most of the measurements were averaged over less than $2 \mathrm{~km}$, but several of the data were collected during fast ascent or descents and thus were averaged over considerably larger altitude intervals. Figure 2 shows the twodimensional pattern for the PAN measurement locations. For the sake of clarity, only the means of the altitude range are shown in Figure 2. In Figures $3 a-3 e$ the results of the PAN measurements are shown for the different flights, together with the altitude range over which the measurements were integrated.

In Figure $3 a$ the data from the northbound flights between $40^{\circ}$ and $65^{\circ} \mathrm{N}$ are presented; in Figure $3 b$, results from the southbound flights between $65^{\circ}$ and $15^{\circ} \mathrm{N}$; in Figure $3 c$, data from the northbound flights between $5^{\circ} \mathrm{S}$ and $40^{\circ} \mathrm{N}$, in Figure $3 d$, data from the southbound flights from $2^{\circ}$ to $60^{\circ} \mathrm{S}$; and finally, Figure $3 e$ shows the results of the northbound flights between $50^{\circ}$ and $5^{\circ} \mathrm{S}$. It should be noted that Figure $3 a$ and $3 b$ differ from Figures $3 c-3 e$ by a factor of 5 in the mixing ratio scale. The results of the measurements made at the different airports directly before takeoff or after landing are listed in Table 1.

\section{Discussion}

\section{Two-Dimensional Distribution of PAN}

In order to obtain an overview of the results of the PAN measurements made during the STRATOZ III flights, the data from Figures $3 a-3 e$ are combined to produce two-dimensional 


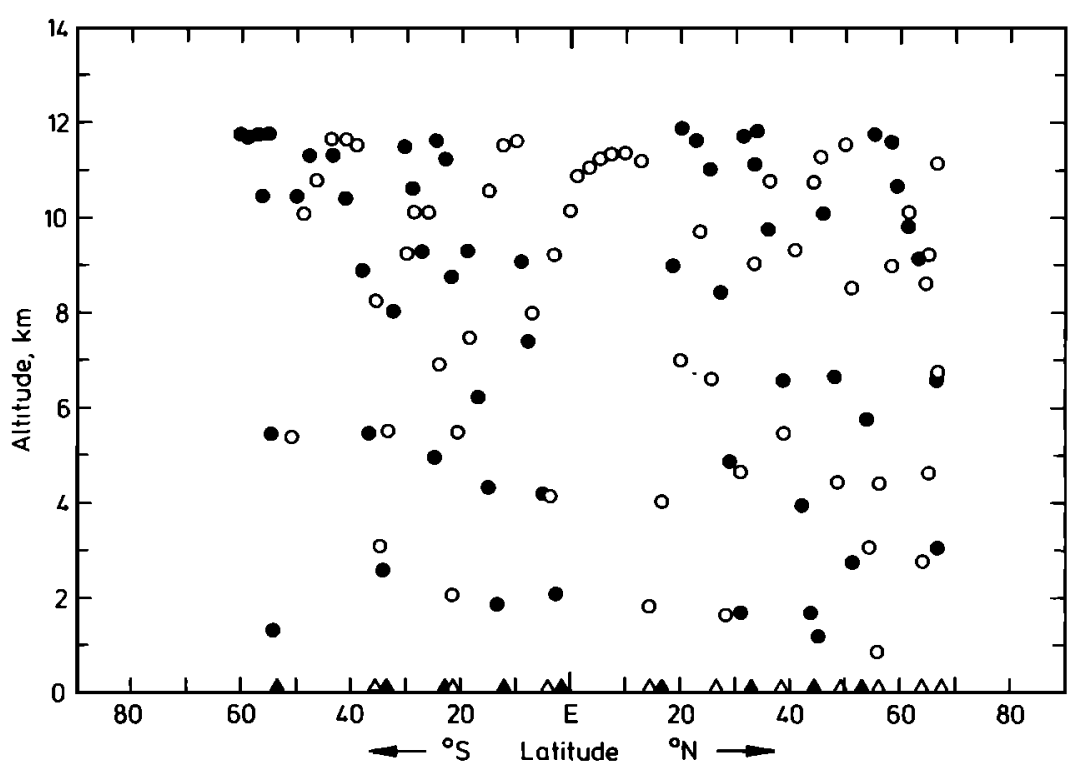

Fig. 2. Two-dimensional sample collection pattern for the STRATOZ III flights. Open circles indicate northbound flights; full circles indicate southbound flights; and triangles indicate measurements made at airports.

distributions (Figures $4 a$ and $4 b$ ). The data from the northbound and the southbound flights are used separately because of the quite different flight routes, especially in the northern hemisphere (Figure 1). Only the data points between $50^{\circ}$ and $60^{\circ} \mathrm{S}$ from the flight from Punta Arenas to Punta Arenas were used for both distributions.

For the southbound flights the distribution is not shown between $15^{\circ} \mathrm{N}$ and $2^{\circ} \mathrm{S}$ because no PAN data were collected in this region and any interpolation over such a wide latitude range would be extremely uncertain. Also, we did not try to interpolate between the results obtained from the flight from Lisbon to Bretigny and the flight from Bretigny to Prestwick because these two flights were made about 3 weeks apart and the meteorological situation had changed considerably. As the wind directions, shown in Figure 1, already indicate, these two flights were performed under very different meteorological conditions. While in both cases an upper air trough over the whole of Europe (trough line NW to SE) was the dominant feature in the $500-\mathrm{hPa}$ charts, the flights were conducted at the (warmer) eastern side (June 4) and the (colder) western side (June 26) of the trough line, respectively, Therefore very different air masses, continental on June 4 and rather remote on June 26, were sampled during these particular flights.

It is evident that the data obtained during the STRATOZ III flights represent only a momentary situation and should not be considered as a global or long-term average. Still, each of the measurements were averaged over a horizontal distance of $150-200 \mathrm{~km}$, as mentioned before. Furthermore, the lifetime of PAN in the middle and upper troposphere is quite long [Crutzen, 1979; Fishman and Carney, 1984; Brewer et al., 1983], and thus we can expect that our measurements, although limited in their number, will give a reasonable first glance at the large-scale two-dimensional distribution of PAN and such two-dimensional results should show the most prominent features.

The situation in the southern hemisphere is rather simple. With the exception of the highest part of the troposphere and a region at low latitudes which show somewhat higher mixing ratios, all PAN measurements are in the range from 7 to 10 ppt. The region of slightly increased PAN at low southern latitudes is shaped somewhat differently and is slightly shifted toward higher latitudes (at low altitudes) for the northbound flights. As can be seen from Figure 1, these regions of elevated PAN coincide with the areas over which the wind direction indicates that the air masses are continentally influenced.

In comparison to the southern hemisphere PAN distribution the situation for the northern hemisphere is rather complex. Not only do the data show a considerable gradient between low and high northern latitudes of a factor of nearly 10 , but also the distribution obtained during the southbound flights differs significantly from the northbound distribution, especially below $40^{\circ} \mathrm{N}$. The PAN values observed during the flight along the east coast of North America were considerably higher than over the African west coast. This most probably reflects the impact of the United States as large industrialized area. Indeed, the air masses encountered during these flights originated from over the United States.

In contrast to this, measurements along the African coast show very low PAN values, comparable to those in the southern hemisphere. At about $30^{\circ} \mathrm{N}$ they are still in the range of 10 ppt in the lower and middle troposphere, and no values above 25 ppt are observed south of Lisbon $\left(39^{\circ} \mathrm{N}\right)$. During June 24-26 a large and very persistent high-pressure system is displayed on the upper air $(500 \mathrm{hPa})$ charts, which extended up to the 200-hPa level. Its center was located over central Algeria, and the whole system ranged from Dakar to south of Tripolis. Therefore between $12^{\circ}-20^{\circ} \mathrm{N}$, easterly wind directions prevailed along the flight route, while north of $25^{\circ} \mathrm{N}$ up to Lisbon $\left(39^{\circ} \mathrm{N}\right)$, air masses from $\mathrm{SW}$ to $\mathrm{W}$ arrived from the open Atlantic Ocean. Thus the rather low PAN mixing ratios observed over this region are not surprising. Similar to our observations in the southern hemisphere, we also see for this area a slight increase of the PAN mixing ratios in the highest troposphere.

Compared to this, we observe a very different situation over northern Europe and along the North American east coast, 

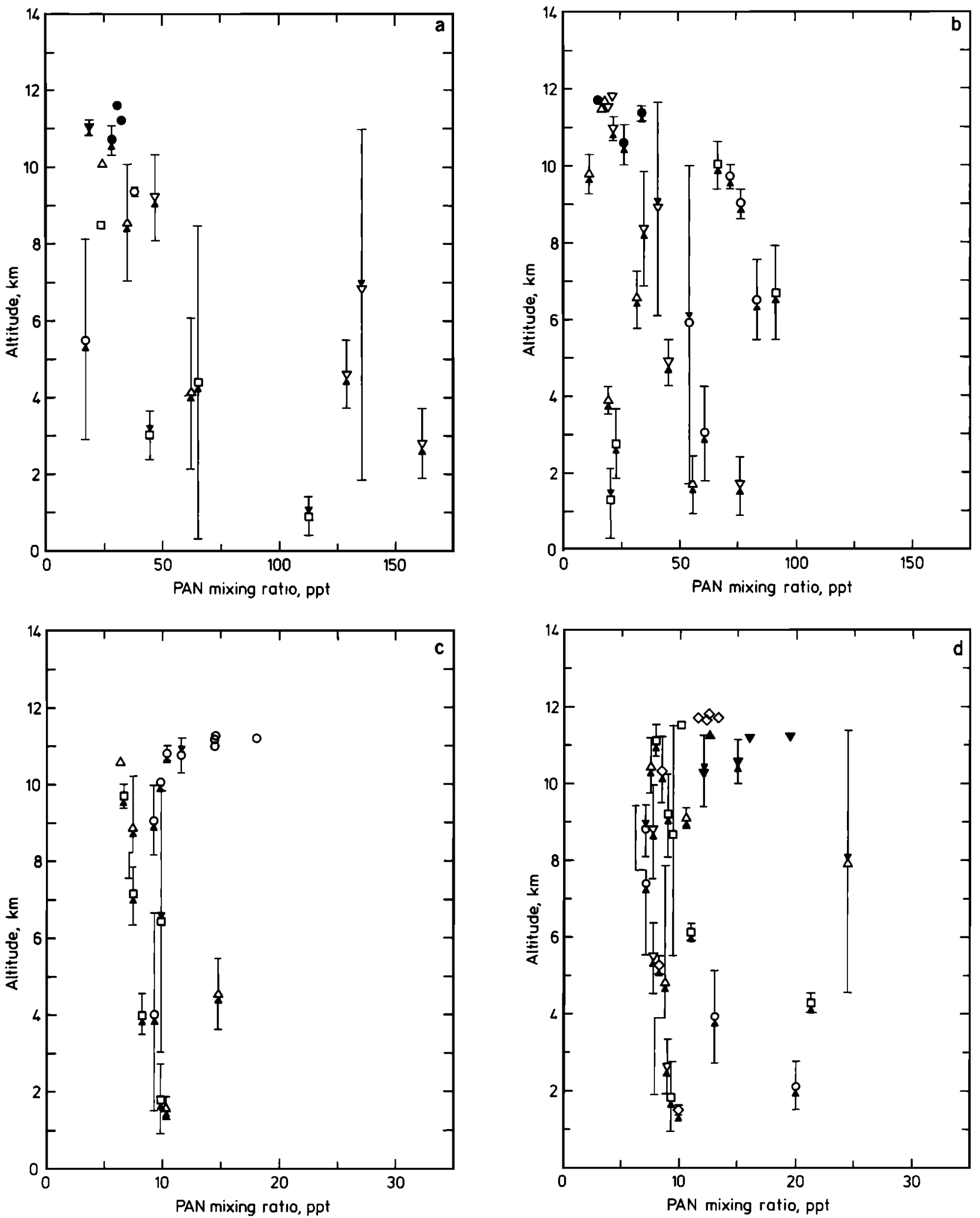

Fig. 3. Vertical profiles of PAN measured during the different flight legs. The arrows indicate whether the measurements were made during ascent or descent. The vertical bars show the altitude range over which the measurement integrated. Solid symbols indicate that the measurement was made mainly in the lowest stratosphere. (a) Circles indicate the flight leg from Lisbon to Bretigny; squares, the flight leg from Bretigny to Prestwick; triangles, the flight leg from Prestwick to Keflavik; and inverted triangles, the flight leg from Keflavik to Sondrestrom. (b) Circles indicate the fight leg from Sondrestrom to Goose Bay; squares, the flight leg from Goose Bay to Halifax; triangles, the flight leg from Halifax to Bermuda; and inverted triangles, the flight leg from Bermuda to Pointe à Pitré. (c) Circles indicate the flight leg from Natal to Dakar; squares, the flight leg from Dakar to Las Palmas; and triangles, the flight leg from Las Palmas to Lisbon. (d) Circles indicate the flight leg from Guayaquil to Lima; squares, the flight leg from Lima to Antofagasta; triangles, the flight leg from Antofagasta to Santiago; and inverted triangles, the flight leg from Santiago to Punta Arenas. (e) Circles indicate the flight leg from Punta Arenas to Buenos Aires; squares, the flight leg from Buenos Ares to Rio de Janeiro; and triangles, the flight leg from Rio de Janeiro to Natal. 


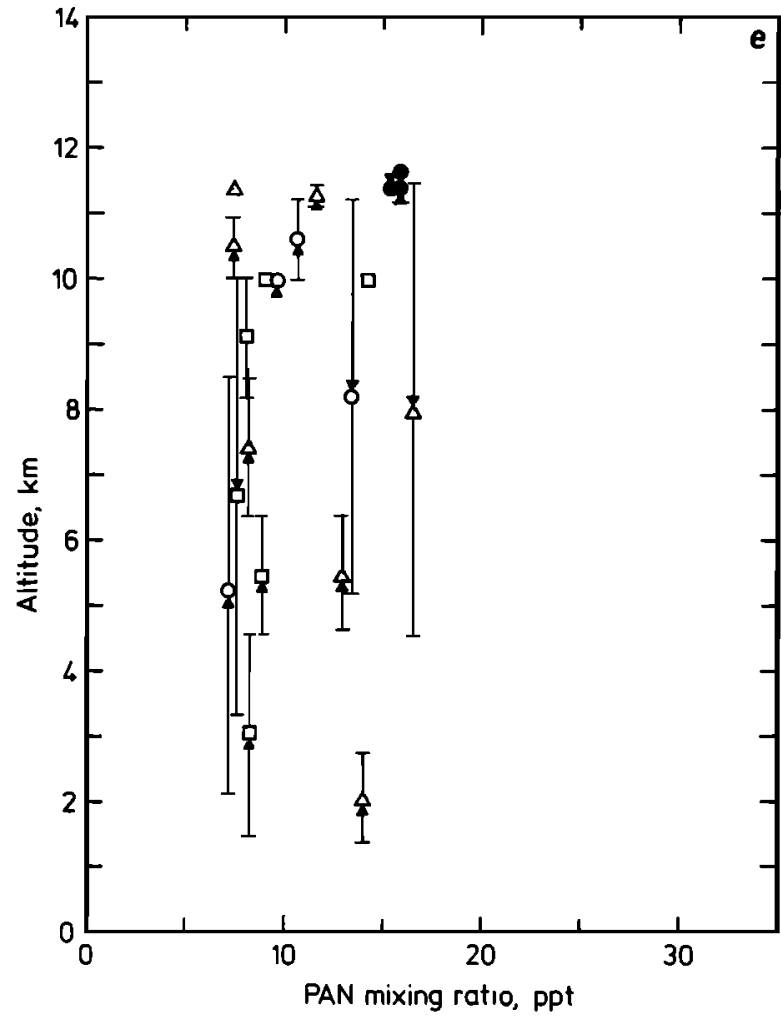

Fig. 3. (Continued)

with wind directions mainly from Europe or North America. At high and mid northern latitudes the PAN mixing ratios are in the range of 60-100 ppt and sometimes even higher, decreasing toward the tropopause and the lower stratosphere to 15-25 ppt, in some areas even to 10-15 ppt. In the latitude range around $40^{\circ}-50^{\circ} \mathrm{N}$ along the North American coast, the PAN mixing ratios show a surprising minimum, with low PAN values down to $15-25$ ppt at low altitudes. On June 6 a pronounced polar jet stream from NW to SE was situated over Halifax, while on June 7 its axis moved slightly southward. Stratospheric-tropospheric exchange processes which are associated with such strong wind bands at the tropopause level could be shown to be active even in this geographical region [Ehhalt et al., 1985]. Therefore the potential influence of those transport processes should be basically considered regarding the vertical distribution pattern of PAN at these latitudes. The PAN mixing ratios during the southbound flights below $8 \mathrm{~km}$ altitude are, with $35-60 \mathrm{ppt}$ between $16^{\circ}$ and $35^{\circ} \mathrm{N}$, a factor of approximately 5 higher compared to the northbound flights at the same latitudes. Unfortunately, the location and shape of the north-south gradient is not very well defined for the southbound flights as a result of the lack of data between $16^{\circ} \mathrm{N}$ and $2^{\circ} \mathrm{S}$. However, from Figure $4 a$ it is evident that this decrease occurs in the latitude range between $20^{\circ} \mathrm{N}$ and the equator.

Our surface-level measurements during the STRATOZ III experiment were all made at airports and thus might have been subject to more or less strong local influences. Some of the airports are located rather close to major cities (Guayaquil, Lima, Santiago de Chile, Buenos Aires, Rio de Janeiro, and Bretigny), and we have to accept the possibility of severe local influence on the measured PAN mixing ratios at these airports. For the other airports we also cannot completely rule out local influences; however, these eflects should be rather low.
TABLE 1. PAN Measurements at Airports During the STRATOZ III Flights

\begin{tabular}{|c|c|c|c|c|}
\hline Airport & $\begin{array}{l}\text { Date } \\
(1984)\end{array}$ & $\begin{array}{l}\text { Time, } \\
\text { UT }\end{array}$ & $\begin{array}{l}\text { Latitude/ } \\
\text { Longitude }\end{array}$ & $\begin{array}{c}\text { PAN Mixing } \\
\text { ratio, } \\
\text { ppt }\end{array}$ \\
\hline Prestwick & June 4 & 854-914 & $55^{\circ} \mathrm{N} / 5^{\circ} \mathrm{W}$ & 73 \\
\hline Prestwick & June 4 & $939-959$ & $55^{\circ} \mathrm{N} / 5^{\circ} \mathrm{W}$ & 61 \\
\hline Keflavik & June 4 & $1250-1310$ & $64^{\circ} \mathrm{N} / 23^{\circ} \mathrm{W}$ & 50 \\
\hline Sondrestrom & June 5 & $1304-1324$ & $67^{\circ} \mathrm{N} / 51^{\circ} \mathrm{W}$ & 72 \\
\hline Goose Bay & June 6 & $908-928$ & $53^{\circ} \mathrm{N} / 60^{\circ} \mathrm{W}$ & 14 \\
\hline Goose Bay & June 6 & $935-955$ & $53^{\circ} \mathrm{N} / 60^{\circ} \mathrm{W}$ & 18 \\
\hline Goose Bay & June 6 & 1004-1024 & $53^{\circ} \mathrm{N} / 60^{\circ} \mathrm{W}$ & 18 \\
\hline Halifax & June 7 & 1914-1934 & $45^{\circ} \mathrm{N} / 64^{\circ} \mathrm{W}$ & 27 \\
\hline Bermuda & June 8 & $009-029$ & $32^{\circ} \mathrm{N} / 65^{\circ} \mathrm{W}$ & 10 \\
\hline Pointe à Pitré & June 10 & $1055-1115$ & $16^{\circ} \mathrm{N} / 62^{\circ} \mathrm{W}$ & 13.5 \\
\hline Guayaquil & June 13 & $1315-1335$ & $2^{\circ} \mathrm{S} / 80^{\circ} \mathrm{W}$ & 20 \\
\hline Guayaquil & June 13 & $1345-1405$ & $2^{\circ} \mathrm{S} / 80^{\circ} \mathrm{W}$ & 18 \\
\hline Guayaquil & June 13 & $1415-1435$ & $2^{\circ} \mathrm{S} / 80^{\circ} \mathrm{W}$ & 11 \\
\hline Lima & June 13 & $1722-1742$ & $12^{\circ} \mathrm{S} / 77^{\circ} \mathrm{W}$ & 72 \\
\hline Lima & June 14 & $1705-1715$ & $12^{\circ} \mathrm{S} / 77^{\circ} \mathrm{W}$ & 34 \\
\hline Antofagasta & June 14 & $2313-2333$ & $23^{\circ} \mathrm{S} / 70^{\circ} \mathrm{W}$ & 7.2 \\
\hline Antofagasta & June 16 & $854-914$ & $23^{\circ} \mathrm{S} / 70^{\circ} \mathrm{W}$ & 13 \\
\hline Antofagasta & June 16 & $925-945$ & $23^{\circ} \mathrm{S} / 70^{\circ} \mathrm{W}$ & 13 \\
\hline Santiago de Chile & June 16 & $1300-1320$ & $33^{\circ} \mathrm{S} / 71^{\circ} \mathrm{W}$ & 25 \\
\hline Santiago de Chile & June 17 & $1518-1538$ & $33^{\circ} \mathrm{S} / 71^{\circ} \mathrm{W}$ & 280 \\
\hline Puntas Arenas & June 17 & 2018-2038 & $53^{\circ} \mathrm{S} / 71^{\circ} \mathrm{W}$ & 8.8 \\
\hline Puntas Arenas & June 17 & 2048-2108 & $53^{\circ} \mathrm{S} / 71^{\circ} \mathrm{W}$ & 10.6 \\
\hline Puntas Arenas & June 18 & $1636-1656$ & $53^{\circ} \mathrm{S} / 71^{\circ} \mathrm{W}$ & 11.5 \\
\hline Puntas Arenas & June 18 & $2107-2127$ & $53^{\circ} \mathrm{S} / 71^{\circ} \mathrm{W}$ & 14 \\
\hline Puntas Arenas & June 19 & $1349-1409$ & $53^{\circ} \mathrm{S} / 71^{\circ} \mathrm{W}$ & 11.7 \\
\hline Buenos Aires & June 19 & $1923-1943$ & $35^{\circ} \mathrm{S} / 58^{\circ} \mathrm{W}$ & 9 \\
\hline Rio de Janeiro & June 20 & $1935-1955$ & $23^{\circ} \mathrm{S} / 43^{\circ} \mathrm{W}$ & 309 \\
\hline Rio de Janeiro & June 20 & 2005-2025 & $23^{\circ} \mathrm{S} / 43^{\circ} \mathrm{W}$ & 196 \\
\hline Rio de Janeiro & June 22 & $1549-1609$ & $23^{\circ} \mathrm{S} / 43^{\circ} \mathrm{W}$ & 150 \\
\hline Rio de Janeiro & June 22 & $1620-1640$ & $23^{\circ} \mathrm{S} / 43^{\circ} \mathrm{W}$ & 258 \\
\hline Natal & June 22 & $2107-2117$ & $6^{\circ} \mathrm{S} / 35^{\circ} \mathrm{W}$ & 10 \\
\hline Natal & June 24 & $1044-1104$ & $6^{\circ} \mathrm{S} / 35^{\circ} \mathrm{W}$ & 8 \\
\hline Natal & June 24 & $1114-1134$ & $6^{\circ} \mathrm{S} / 35^{\circ} \mathrm{W}$ & 8 \\
\hline Dakar & June 24 & $1700-1720$ & $15^{\circ} \mathrm{N} / 17^{\circ} \mathrm{W}$ & 6.5 \\
\hline Dakar & June 24 & $1731-1751$ & $15^{\circ} \mathrm{N} / 17^{\circ} \mathrm{W}$ & 6.5 \\
\hline Dakar & June 25 & $712-732$ & $15^{\circ} \mathrm{N} / 17^{\circ} \mathrm{W}$ & 7 \\
\hline Dakar & June 25 & $742-802$ & $15^{\circ} \mathrm{N} / 17^{\circ} \mathrm{W}$ & 10 \\
\hline Las Palmas & June 25 & $1136-1156$ & $28^{\circ} \mathrm{N} / 15^{\circ} \mathrm{W}$ & 8 \\
\hline Las Palmas & June 26 & $1053-1113$ & $28^{\circ} \mathrm{N} / 15^{\circ} \mathrm{W}$ & 5 \\
\hline Las Palmas & June 26 & $1123-1143$ & $28^{\circ} \mathrm{N} / 15^{\circ} \mathrm{W}$ & 5 \\
\hline Lisbon & June 26 & $1429-1449$ & $39^{\circ} \mathrm{N} / 9^{\circ} \mathrm{W}$ & 93 \\
\hline Lisbon & June 26 & $1555-1615$ & $39^{\circ} \mathrm{N} / 9^{\circ} \mathrm{W}$ & 43 \\
\hline Lisbon & June 26 & $1625-1645$ & $39^{\circ} \mathrm{N} / 9^{\circ} \mathrm{W}$ & 46 \\
\hline Lisbon & June 26 & $1655-1715$ & $39^{\circ} \mathbf{N} / 9^{\circ} \mathrm{W}$ & 69 \\
\hline Bretigny & June 26 & $2050-2110$ & $45^{\circ} \mathrm{N} / 2^{\circ} \mathrm{E}$ & 182 \\
\hline
\end{tabular}

Except for the measurements at Goose Bay (slightly less than $20 \mathrm{ppt}$ ), all other ground level data from north of $50^{\circ} \mathrm{N}$ are around 50-70 ppt and thus quite similar in magnitude to the values found in the free troposphere at these latitudes. It is interesting to note that not only at Goose Bay, but also at Halifax, Bermuda, and Pointe à Pitré, the PAN mixing ratios were rather low (10 or $13.5 \mathrm{ppt}$, respectively), in general, even lower than in the free troposphere above these areas.

The PAN mixing ratios at Antofagasta $\left(23^{\circ} \mathrm{S}\right)$ and Punta Arenas $\left(53^{\circ} \mathrm{S}\right)$ show similar values, ranging around $11 \mathrm{ppt}$ $(11.2 \pm 2.1 \mathrm{ppt})$. However, in contrast to the northern hemispheric data these values are comparable or even higher than the PAN mixing ratios generally observed in the free southern hemispheric troposphere. At Natal, Dakar, and Las Palmas we found somewhat lower mixing ratios around $7 \mathrm{ppt}$ $(7.4 \pm 1.7 \mathrm{ppt})$, slightly lower than above these regions in the free troposphere. 

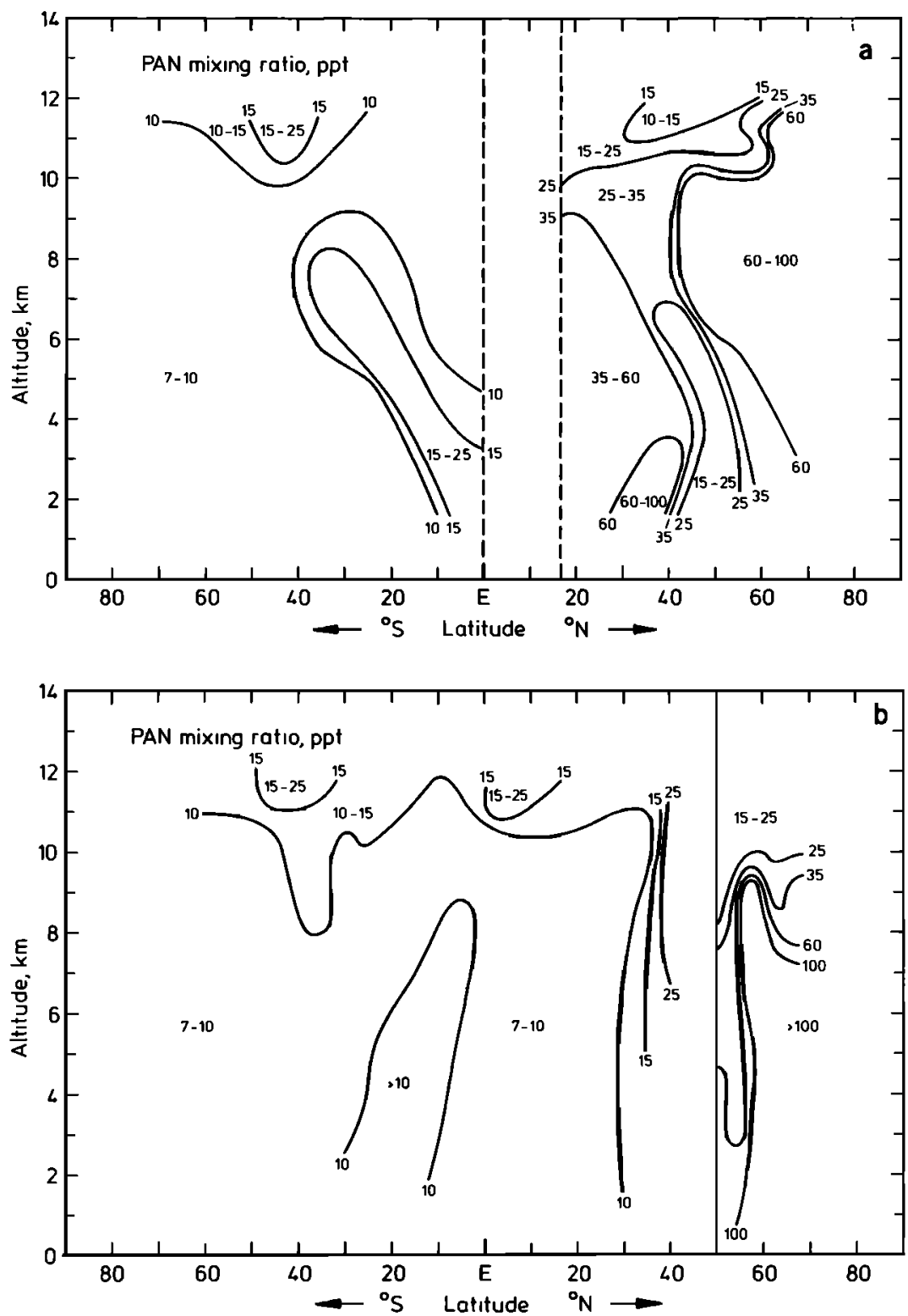

Fig. 4. Two-dimensional distributions for PAN derived from the data in Figure 3. (a) Southbound flights. (b) Northbound flights.

\section{Vertical Profiles of PAN}

As already mentioned, the results of our measurements indicate a good deal of variability for the atmospheric PAN mixing ratios, and consequently, the two-dimensional distribution in Figure 4 can only show the most pronounced features of the atmospheric PAN profiles. Thus a more detailed look at the individual profiles seems worthwhile. The PAN profiles shown in Figures $3 a-3 e$ present a combination of the vertical and horizontal (in most cases latitudinal) variability of PAN.

Some of the measurements were made in the lowest part of the stratosphere, just above the tropopause. These data points are shown as solid points in Figure 3. The identification of PAN measurements made in the stratosphere is based on in flight ozone and temperature measurements. The results obtained from other trace gas measurements, including $\mathrm{CO}$ and $\mathrm{CH}_{4}$, confirmed that predominately stratospheric air was sam- pled for these measurement points, although the time resolution, and thus the altitudinal and latitudinal resolution, of most of the trace gas measurements were not as good as for temperature and ozone. Because of the limited maximum flight level of the airplane (slightly less than $12 \mathrm{~km}$ ), only a limited number of data points are from the stratosphere. Moreover, the stratospheric measurements are restricted to situations and regions with relatively low tropopause levels, e.g., higher latitudes.

The eight southern hemispheric data from the lowest stratosphere range from 12 to $20 \mathrm{ppt}$, with an average value of 15.2 ppt and a variance of $2.3 \mathrm{ppt}$. Surprisingly, these values are significantly higher than the PAN mixing ratios we generally observed in the free troposphere of the southern hemisphere. This may have different reasons: quasi-horizontal transport from areas with higher PAN mixing ratios or increased in situ photochemical formation of PAN due to the increased $\mathrm{NO}_{x}$ levels at higher altitudes in this region observed during the 
STRATOZ III flights (J. Drummond, D. H. Ehhalt, and A. Volz, Nitric oxide measurements obtained during STRATOZ III, submitted to the Journal of Geophysical Research, 1987).

The northern hemispheric PAN mixing ratios found in the lowest stratosphere are slightly higher, with a considerably larger scatter (between 15 and $35 \mathrm{ppt}$ ), an average of $26.1 \mathrm{ppt}$, and a variance of $7.2 \mathrm{ppt}$. Since the tropospheric PAN mixing ratios we observed at mid and high northern latitudes are in general much higher, we cannot easily decide to what extent troposphere-stratosphere exchange or in situ production contribute to the stratospheric PAN in the northern hemisphere.

The data in Figures $3 a$ and $3 b$ show no significant vertical gradient except for the uppermost part of the troposphere. However, the scatter of the PAN mixing ratios, most probably the result of varying continental influence on the different air masses, does not allow us to recognize smaller effects. Nevertheless, the decrease of the PAN mixing ratios around $10 \mathrm{~km}$ altitude and above is rather pronounced and is clearly visible in spite of the large variability of the data.

However, this picture is only seen for regions which are substantially influenced by strong anthropogenic activities. It can be seen clearly from the wind directions shown in Figure 1 and the results shown in Figures $3 a-3 e$ that the PAN mixing ratios are considerably elevated in the cases with the wind direction either from over Europe or North America. Both the data from the southern hemisphere (Figures $3 d$ and $3 e$ ) and those from the African east coast up to $40^{\circ} \mathrm{N}$ show much lower PAN mixing ratios and a lower variability. In contrast to the decrease towards higher altitudes at $10 \mathrm{~km}$ and above, seen in Figures $3 a$ and $3 b$, the profiles shown in Figures $3 c-3 e$ indicate an increase of PAN at $10 \mathrm{~km}$ and above, even if the stratospheric data are excluded. Since our southern hemispheric data indicate that the background PAN mixing ratios in the southern hemisphere are significantly lower, this is an indication that the PAN levels observed in the lowest stratosphere and uppermost troposphere are due to in situ photochemical production. However, our data only cover a part of the southern hemisphere and thus quasi-horizontal transport cannot be ruled out, especially if the long atmospheric residence time of PAN at low temperatures is taken into consideration.

At the temperatures we observed during the flights in the altitude range of $5 \mathrm{~km}$ and above, the atmospheric lifetime of PAN is estimated to be considerably longer than 1 month [e.g., Crutzen, 1979]. This is long enough to allow horizontal or quasi-horizontal motion of air masses on a very large scale.

If we exclude the PAN values from altitudes above $10 \mathrm{~km}$, the southern hemispheric PAN mixing ratios are mostly in the range from 7 to $11 \mathrm{ppt}$. Only at lower latitudes, roughly between $20^{\circ} \mathrm{S}$ and the equator, do we observe somewhat higher values. The wind direction from Figure 1 indicates that air with continental influence was sampled in this region. This points towards the existence of significant sources of PAN, or its precursors, in tropical South America, although the observed PAN levels are still small compared to values at mid and high northern latitudes.

Apart from the two exceptions, altitudes of $10 \mathrm{~km}$ and above and measurements with air from tropical South America, the southern hemispheric PAN mixing ratios are surprisingly constant, with an average of $8.5 \mathrm{ppt}$ and a variance of only $1.1 \mathrm{ppt}$ (this variance only slightly exceeds the purely experimental error). These southern hemispheric data are comparable with the average value we observed along the east coast of Africa between $10^{\circ}$ and $30^{\circ} \mathrm{N}$ and at altitudes below $10 \mathrm{~km}: 9.3 \mathrm{ppt}$ with a variance of $2.3 \mathrm{ppt}$. Both for the southern hemisphere and the coast of Africa (Figures $3 c-3 e$ ) there is no indication for a vertical PAN gradient in the free troposphere below $10 \mathrm{~km}$ altitude. These rather uniform distributions of PAN in the free troposphere remote from large PAN (or PAN precursor) sources is easily understood if the atmospheric lifetime of PAN at low temperatures is considered. Crutzen [1979] estimated that the average atmospheric lifetime of PAN at $275 \mathrm{~K}$ is about 3 days, increasing to 4 weeks at $262 \mathrm{~K}$, and to even longer lifetimes at temperatures below $262 \mathrm{~K}$. During all our PAN measurements above ground level we observed only eight measurements with inflight air temperatures of more than $275 \mathrm{~K}$, with one exception (the flight from Natal to Dakar at $4 \mathrm{~km}$ altitude) all below 2 $\mathrm{km}$ altitude. Furthermore, above $5 \mathrm{~km}$ the atmospheric temperature was generally below $265 \mathrm{~K}$, and thus the PAN lifetime is of the order of 1 month and longer.

\section{Comparison With Other Measurements and Model Calculations}

There are a few published data of PAN measurements in the free troposphere which may be compared with our data. Singh and Salas [1983] reported the results of measurements made during different airplane flights in September 1982 west of the Californian coast over the Pacific. With the exception of one flight, the PAN mixing ratios were in the range of 10-100 ppt, quite similar to the values we found at the same latitude along the American east coast. Further measurements Singh and Salas made in August west of the Californian coast gave similar results of 8-60 ppt PAN in the free troposphere. However, the values they observed in February 1985 (50-400 ppt) were considerably higher [Singh et al., 1986]. In the same paper, measurements in July 1984 from the free troposphere over the continental United States (Colorado) are presented. The PAN mixing ratios were in the range of 100-200 ppt. Even higher values (sometimes of more than $1 \mathrm{ppb}$ ) were reported for 2-4 km altitude over central Germany in September/October 1983 [Meyrahn et al., 1984].

Singh et al. [1986] included in their paper the results of PAN measurements made at surface level during a ship cruise in November 1984 between $48^{\circ} \mathrm{N}$ and $53^{\circ} \mathrm{S}$ over the Pacific. They report $38 \mathrm{ppt}$ as the northern hemispheric average and 5 ppt as the southern hemispheric average. Our southern hemispheric mixing ratios at ground level are somewhat higher (11 ppt compared to $5 \mathrm{ppt}$ ) than the values reported by Singh et al. [1986]. For the northern hemisphere they are in the same range as the data of Singh et al. for November 1984, but the large variability of the PAN mixing ratios in the northern hemisphere would conceal smaller systematic differences which might be seen in the southern hemisphere. Singh et al. [1986] hypothesized that the PAN mixing ratios in the atmosphere show a significant seasonal cycle with maximum values in winter, due to the strong temperature dependence of the atmospheric PAN lifetime. This is in agreement with the observation that the PAN measurements made by Singh et al. [1986] during the southern hemispheric summer are somewhat lower than our winter data, but the very limited presently known data sets on atmosphere PAN mixing ratios are not sufficient to confirm this hypothesis. There are no published 
measurements of PAN in the stratosphere or in the tropopause range known to us.

There are some predictions of the tropospheric PAN mixing ratios at mid-latitudes based on model calculations. Fishman and Carney [1984] predict PAN mixing ratios in the range of 30-50 ppt for the free troposphere, comparable to values calculated by Brewer et al. [1983] of about 35 ppt for standard hydrocarbon emissions. Singh and Hanst [1981] estimate PAN mixing ratios of 17 ppt for the lower troposphere, 90-350 ppt for the upper troposphere (depending on the exchange rate between lower and upper troposphere) and 85 ppt for the lower stratosphere.

In general, these values are comparable to our measurements at mid-latitudes up to $10-\mathrm{km}$ altitudes, although our measurements are on the lower side of the predictions of Singh and Hanst for the upper troposphere. Our stratospheric measurements, and the data from the highest troposphere are significantly lower than the estimates of Singh and Hanst. However, the rather large variability of our data at latitudes north of $40^{\circ} \mathrm{N}$ does not allow a detailed comparison with model calculations.

There exist a very limited number of studies of PAN and some of the PAN precursors at remote continental sites at ground level [Singh et al., 1985; Fahey et al., 1986; Bottenheim et al., 1986]. From these studies it seems that at low levels of $\mathrm{NO}_{x}\left(\mathrm{NO}_{x}: \mathrm{NO}+\mathrm{NO}_{2}\right)$ the atmospheric PAN mixing ratios are comparable to the $\mathrm{NO}_{x}$ mixing ratios. At levels of $\mathrm{NO}_{x}$ below $0.1 \mathrm{ppb}$ there are indications that the PAN/NO $\mathrm{NO}_{x}$ ratio is increasing and may exceed 1 [Singh et al., 1985]. However, no comparable measurements have been published from above ground level. Even the available data for $\mathrm{NO}_{x}$ measurements in the remote, free troposphere are very limited. Dickerson [1985] reports $\mathrm{NO}_{x}$ values ranging from a tenth of a ppb to a few tenths of a ppb for altitudes up to $6.5 \mathrm{~km}$ over northern Scandinavia $\left(74^{\circ}-83^{\circ} \mathrm{N}\right)$ in March 1983. Our PAN data for about $65^{\circ}-70^{\circ} \mathrm{N}$ below $7 \mathrm{~km}$ are in the range of a tenth of a ppb $(0.1 \pm 0.04 \mathrm{ppb})$. From airplane flights over Wyoming, Kley et al. [1981] report $\mathrm{NO}_{x}$ values in the range of a tenth of a ppb as lower limit for $4-7 \mathrm{~km}$ altitude, increasing significnatly with decreasing altitude. Volz and Drummond [1984] measured $\mathrm{NO}_{x}$ values between 40 and 100 ppt over southern Germany at altitudes from 1 to $7 \mathrm{~km}$. Ehhalt and Drummond [1982] estimated $\mathrm{NO}_{x}$ values of 50-70 ppt for the free troposphere over the Pacific from the NO measurements made by Schiff et al. [1979] during the "Gametag" flights.

These $\mathrm{NO}_{x}$ data are, in general, of a magnitude similar to our PAN measurements from over Europe and the east coast of North America, but they are considerably larger than the PAN values observed along the west coast of Africa. No published $\mathrm{NO}_{x}$ measurements from the remote free troposphere in the southern hemisphere are known to us. There are some southern hemispheric measurements of $\mathrm{NO}_{x}$ in marine air. $\mathrm{NO}_{x}$ mixing ratios of around $10 \mathrm{ppt}$ are reported by $\mathrm{McFar}$ land et al. [1979] for the equatorial Pacific. Broll et al. [1984] report $\mathrm{NO}_{2}$ measurements at nighttime over the Atlantic. Since during nighttime in clear air masses essentially all NO is transformed into $\mathrm{NO}_{2}$, their measurements of $\mathrm{NO}_{2}$ in the range of 30-40 ppt for the southern Atlantic can be used as $\mathrm{NO}_{x}$ values for our comparison. Both our ground-level and free tropospheric data from the southern hemisphere and equatorial regions (around $10 \mathrm{ppt}$ ) are similar to the Pacific $\mathrm{NO}_{x}$ values of McFarland et al., but they are somewhat lower than the values of Broll et al. from over the Atlantic. These data indicate that PAN and $\mathrm{NO}_{x}$ in the free, remote troposphere are present at mixing ratios of similar orders of magnitude, probably with $\mathrm{PAN} / \mathrm{NO}_{x}$ ratios somewhat smaller than unity. However, the available data set for such a comparison is very limited and does not allow any final conclusions.

\section{CONCLUSIONS}

The observed mixing ratios for PAN in the free troposphere range from slightly below $10 \mathrm{ppt}$ in the southern hemisphere to more than 100 ppt at high northern latitudes. The data show that Europe and North America are important source areas for PAN or precursors of PAN. There are indications that the tropical areas of South America also act as sources for PAN or PAN precursors; however, the observed effects are much lower than for Europe and North America. The southern hemisphere PAN mixing ratios in marine air are very uniform, averaging around $8.5 \mathrm{ppt}$. In the northern hemisphere in air masses free from industrial or urban influences, PAN is slightly higher (around $9.5 \mathrm{ppt}$ ) and shows a larger variability. These values are considerably lower than the free tropospheric PAN mixing ratios reported by Singh and Salas [1983] and Singh et al. [1986]. Compared to these "clean-air conditions," significantly elevated PAN mixing ratios in the uppermost troposphere and lowest stratosphere indicate that at least for this altitude range, in situ formation of PAN may be important.

The substantially elevated PAN mixing ratios at mid and high northern latitudes are most probably the result of industrial and urban air pollution over Europe and Northern America. Because of the rather long atmospheric lifetime of PAN in the free troposphere, PAN can be transported over long distances. Thus our measurements do not allow us to differentiate between long-range transport of PAN and in situ formation of PAN from transported precursors of PAN (nonmethane hydrocarbons and $\mathrm{NO}_{x}$ ).

The measurements show that PAN is present in the free troposphere at low but still significant levels. The current knowledge of the global distribution of PAN is still far from being complete. Especially, the possible existence of a seasonal cycle with maximum PAN values in winter should be investigated by more detailed measurement series. Furthermore, data from simultaneous measurements of PAN and its precursors from the free troposphere are lacking. Finally, it should be noted that the existing model estimates of free tropospheric and lower stratospheric PAN mixing ratios do not give a very good picture of the actually observed values under clean air conditions.

Acknowledgments. The authors thank F. Karcher from EERM (Toulouse) who organized this flight and the other participants in this flight for their valuable assistance during the flight and the flight preparations. The authors also would like to thank the crew of the airplane from the Centre d'Essais en Vol at Bretigny. This work was supported financially by the Bundesministerium für Forschung and Technologie of the Federal Republic of Germany. Most of the meterological data were provided by the German Weather Service. We also thank A. Marenco, who made his ozone measurements from the STRATOZ III flights available to us.

\section{REFERENCES}

Bottenheim, J. W., A. G. Gallant, and K. A. Brice, Measurements of $\mathrm{NO}_{y}$ species and $\mathrm{O}_{3}$ at $82^{\circ} \mathrm{N}$ latitude, Geophys. Res. Lett., 13, 113$116,1986$. 
Brewer, D. A., T. R. Augustsson, and J. S. Levine, The photochemistry of anthropogenic nonmethane hydrocarbons in the troposphere, J. Geophys. Res., 88, 6683-6695, 1983.

Brice, K. A., S. A. Penkett, D. H. F. Atkins, F. J. Sandalls, D. J. Bamber, A. F. Tuck, and G. Vaughn, Atmospheric measurements of peroxyacetylnitrate (PAN) in rural, south-east england: Seasonal variations, winter photochemistry and long-range transport, Atmos. Environ., 18, 2691-2702, 1984.

Broll, A., G. Helas, K. J. Rumpel, and P. Warneck, NO background mixing ratios in surface air over Europe and the Atlantic Ocean, in Proceedings of the 3rd European Symposium on Physico-Chemical Behaviour of Atmospheric Pollutants, Varese, Italy, 1984, edited by B. Versino and G. Angeletti, D. Reidel, pp. 390-400, Hingham, Mass., 1984.

Crutzen, P. J., The role of $\mathrm{NO}$ and $\mathrm{NO}_{2}$ in the chemistry of the troposphere and stratosphere, Ann. Res. Earth Planet. Sci., 7, 443$472,1979$.

Dickerson, R. R., Reactive nitrogen compounds in the arctic, J. Geophys. Res., 90, 10,739-10,743, 1985.

Ehhalt, D. H., and J. W. Drummond, The tropospheric cycle of $\mathrm{NO}_{x}$, in: Chemistry of the Unpolluted and Polluted Troposphere, Proceedings of the NATO Advanced Study Institute, Corfu, 28 Sept.-10 Oct. 1981, edited by H. W. Georgii and W. Jaeschke, pp. 219-251, D. Reidel, Hingham, Mass., 1982.

Ehhalt, D. H., J. Rudolph, F. Meixner, and U. Schmidt, Measurements of selected $\mathrm{C}_{2}-\mathrm{C}_{5}$ hydrocarbons in the background troposphere: Vertical and latitudinal variations, J. Atmos. Chem., 3, 29-52, 1985.

Fahey, D. W., G. Hübler, D. D. Parrish, E. J. Williams, R. B. Norton, B. A. Ridley, H. B. Singh, S. C. Liu, and F. C. Fehsenfeld, Reactive nitrogen species in the troposphere: Measurements of $\mathrm{NO}, \mathrm{NO}_{2}$, $\mathrm{HNO}_{3}$, particulate nitrate, peroxyacetylnitrate (PAN), $\mathrm{O}_{3}$, and total reactive odd nitrogen (NO, at Niwot Ridge, Colorado, $J$. Geophys. Res., 91, 9781-9793, 1986.

Fishman, J., and T. A. Carney, A one-dimensional photochemical model of the troposphere with planetary boundary-layer parameterization, J. Atmos. Chem., 1, 351-376, 1984.

Kley, D., J. W. Drummond, M. McFarland, and S. C. Liu, Tropospheric profiles of $\mathrm{NO}_{x}, J$. Geophys. Res., 86, 3153-3163, 1981.

McFarland, M., D. Kley, J. W. Drummond, A. L. Schmeltekopf, and R. H. Winkler, Nitric oxide measurements in the equatorial Pacific region, Geophys. Res. Lett., 6, 605-608, 1979.

Meyrahn, H., J. Hahn, G. Helas, P. Warneck, and S. A. Penkett, Cryogenic sampling and analysis of peroxyacetyl nitrate in the at- mosphere, in Proceedings of the 3rd European Symposium on Physico-Chemical Behaviour of Atmospheric Pollutants, Varese, Italy, 1984, edited by B. Versino und G. Angeletti, pp. 38-43, D. Reidel, Hingham, Mass., 1984.

Penkett, S. A., F. J. Sandalls, and J. E. Lovelock, Observations of peroxyacetyl nitrate (PAN) in air in southern England, Atmos. Environ., 9, 139-140, 1975.

Schiff, H. I., D. Pepper, and B. A. Ridley, Tropospheric NO measurements up to 7 km, J. Geophys. Res., 84, 7895-7897, 1979.

Singh, H. B., and P. L. Hanst, Peroxyacetyl nitrate (PAN) in the unpolluted atmosphere: An important reservoir for nitrogen oxides, Geophys. Res. Lett., 8, 941-944, 1981.

Singh, H. B., and L. J. Salas, Peroxyacetyl nitrate in the free troposphere, Nature, 302, 326-328, 1983.

Singh, H. B., L. J. Salas, B. A. Ridley, J. D. Shetter, N. M. Donahue, F. C. Fehsenfeld, D. W. Fahey, D. D. Parrish, E. J. Williams, S. C. Liu, G. Hübler, and P. C. Murphy, Relationship between peroxyacetyl nitrate and nitrogen oxides in the clean troposphere, Nature, 318, 347-349, 1985.

Singh, H. B., L. J. Salas, and W. Viezee, The global distribution of peroxyacetyl nitrate, Nature, 321, 588-591, 1986.

Spicer, C. W., M. W. Holdren, and G. W. Keigley, The ubiquity of peroxyacetylnitrate in the continental boundary layer, Atmos. Environ., $17,1055-1058,1983$.

Temple, P. J., and O. L. Taylor, World-wide ambient measurements of peroxyacetyl nitrate (PAN) and implications for plant injury, Atmos. Environ., 17, 1583-1587, 1983.

Vierkorn-Rudolph, B., J. Rudolph, and S. Diederich, Determination of peroxyacetylnitrate (PAN) in unpolluted areas, Int. J. Environ. Anal. Chem., 20, 131-148, 1985.

Volz, A., and J. W. Drummond, Messungen von Stickoxiden im ppt Bereich durch Chemiluminescenz mit $\mathrm{O}_{3}$, Fresenius $Z$. Anal. Chem., $317,355-258,1984$

F. X. Meixner, Fraunhofer-Institut für Atmosphärische Umweltforschung, Kreuzeckbahnstrasse 19, D-8100, GarmischPartenkirchen, Federal Republic of Germany.

J. Rudolph and B. Vierkorn-Rudolph Atmosphärische Chemie, Kernforschungsanlage Jülich G.m.b.H., Postfach 1913, D-5170, Jülich, Federal Republic of Germany.

(Received October 31, 1986; revised March 4, 1987; accepted March 4, 1987.) 